\title{
DOMAIN, GENDER AND AGE DIFFERENCES IN THE CREATIVE BEHAVIOR OF CHILDREN
}

Želiko RAČKI

Faculty of Education, Osijek

UDK: 37.015.3:159.954 159.954-057.87

Izvorni znanstveni rad

Primlieno: 15. 7. 2015.

This study focused on the domain, gender and age differences in the creative behavior of children. The questions on creativity model building were raised because of the significant implications of creativity for education and curricular development, as well as the improvement of creative teaching and teaching to develop creativity in children at the primary school level. The study participants were children aged 8-15, as well as prospective primary school teachers. The results showed the identifiable domain structure of children's creative behavior, gender-specific changes in the domain averages with age, and the close relationships of task commitment and knowledge acquisition with creativity. The findings of this study are discussed in relation to the definition and measurement of creativity construct and in the context of education.

Keywords: creativity, creative-productive giftedness, children, educational goals, Art Bias

Želiko Rački, Josip Jurai Strossmayer University of Osijek, Faculty of Education, Department for Social Sciences, Cara Hadrijana 10, 31000 Osijek, Croatia.

E-mail: zracki@foozos.hr

\section{INTRODUCTION}

Creativity is a complex, multidimensional psychological construct involved in the fulfilment of the human potential to produce, notice and appreciate beauty, excellence and skilled performance in all domains of life - nature, art, science or everyday experience. The standard definition of creativity is 
DRUŠ. ISTRAŽ. ZAGREB GOD. 24 (2015), BR. 4, STR. $467-485$

RAČKI, Ž.: DOMAIN... bipartite: creativity requires both originality and effectiveness (Runco \& Jaeger, 2012). These frugal ingredients are elaborated and iterated throughout various studies on creativity. Primarily, the definitions of creativity, according to which researchers design their studies initially, have to be made very clear.

Creativity in this study is defined as the: (a) observable, manifest, socially acceptable children's behavior consensually described as creative in a given social context, (b) result of the interaction of abilities, knowledge, traits, task commitment and social influences, (c) process at the end of which a child can potentially produce an observable original product. When creativity is measured as a set of behaviors and accomplishments, analyses show that it can be divided into three broad but not entirely distinct domains called: (a) everyday, (b) scientific (or intellectual, mathematical, technical), and (c) artistic (emotional, expressive or performance) creativity (Carson, Peterson, \& Higgins, 2005; Ivcevic, 2007; Wai, Lubinski, \& Benbow, 2005). Research has also shown that creativity is partially domain-specific (Baer \& Kaufman, 2005; Han, 2003; Hong \& Milgram, 2010; Milgram \& Livne, 2005; Silvia, Kaufman, \& Pretz, 2009), containing both general, creativity-relevant processes, such as personality traits, and the specific components, such as domain-relevant processes (Amabile, 1996). Based on the self-report data, creativity displays a hierarchical structure with an over-arching general factor and more specific thematic areas of creative performance (Kaufman, Cole, \& Baer, 2009).

In order to study the domain, gender and age differences connected to the behaviorally defined concept of creativity, two studies were performed, and their results were placed in a developmental and educational context. The first study provided answers to the research questions on the structure of creative behaviors in children, the discriminant validity of creativity domains, and the nature of the domain, gender and age differences in the creative behavior of children. Study 2 aimed to integrate the findings from Study 1 into the educational context and provide guidelines with regard to curriculum building for creativity development.

The participants in the first study were the children, and the participants in the second study were university students of teacher studies. Some of the students included in this sample were in their final year of teacher studies and had already begun their full-time teaching in grades 1-4. These participant samples were chosen based on the fact that all children of the age group considered in this study are obliged to attend primary school in which teachers exert significant influence on their development (e.g., Hattie, 2012). Moreover, teachers have their own specific views on creativity in children (Baer, 2013; Chan \& Yuen, 2014; Runco \& Johnson, 2002), somewhat 
DRUŠ. ISTRAŽ. ZAGREB GOD. 24 (2015), BR. 4 STR. $467-485$

RAČKI, Ž.: DOMAIN... biased towards the arts (i.e., the Art Bias; Glăveanu, 2014; Kaufman \& Baer, 2004). This is especially important because teachers transmit knowledge and skills by means of additional courses, create the classroom and school environment appreciative of creativity, and choose to provide extracurricular activities that nurture a selective, domain-specific creativity (e.g., Rački, Katalenić, \& Gregorović, 2015).

Gender and age expectations, gender role development, knowledge accessibility and the underlying cognitive ability to learn, socioeconomic circumstances, the presence of creative models and mentors, as well as developing vocational interests, all have an influence on children's developing creativity. Research on children's creative behavior is, thus, unavoidably a cross-section of what children pick up from their surroundings, including overt and covert guidelines, and provisions available to them. Because of this, the socially embedded componential model of creativity outlined by Amabile (1996) was used to interpret the findings of this study.

\section{STUDY 1}

\section{Method}

\section{Participants}

The children from five urban elementary schools participated in this study $(n=856)$. At the time they attended the third grade ( $n=289 ; 144$ boys, and 145 girls), the fifth grade $(n=274 ; 139$ boys, and 135 girls), and the seventh grade ( $n=293 ; 154$ boys, and 139 girls), roughly corresponding to 9,11 , or 13 years of age $($ Mage $=11.2$, age range: $8-15)$. An equal number of boys and girls from the third, the fifth, and the seventh grade took part in this study, $\chi^{2}(2, n=856)=0.45, p=0.798$. To account for the multivariate outliers or the missing data, twenty-five cases were removed ( $2.92 \%$ of the entire sample), resulting in 831 cases available for further analyses.

\section{Materials and procedure}

With their parents' informed written consent, the children anonymously and voluntarily filled out one inventory containing concretely stated behaviors that children and adolescents display in their leisure time. The collection of the data and the protection of participant privacy was ensured by following the guidelines stated in the code of ethics of research with children. The behaviors included in the inventory were collected over several years of research conducted by the author of this study, encompassing children aged 8-15 and measuring traits according to The Act Frequency Approach by Buss and Craik (1983). These were found to be a representative pool 
DRUŠ. ISTRAŽ. ZAGREB GOD. 24 (2015), BR. 4, STR. $467-485$

RAČKI, Ž.: DOMAIN... of behaviors ranging from, theoretically, low to high indication of creativity. This initial pool of behaviors was revised, corrected and supplemented using interviews with the children's parents, teachers, as well as the available studies on children's creative behavior. Accordingly, the resulting inventory consisted of 148 behaviors. Some were highly indicative of creativity (e.g., I think up new experiments; I create new choreographies, etc.), and some were fillers (e.g., I watch TV; I surf the Internet). On a scale from 0 (never) to 4 (very often), the children responded how often, in their own opinion, they participated in the listed activities in their leisure time over the previous six months. The social evaluators of creativity, theoretically based on the hypotheses of usefulness of creative work in a group and thus involving social judgment, were used in this study (Consensual Assessment Technique; Amabile, 1982, 1996). Based on the nine educational psychologists' independent ratings of the individual behavior's indication of creativity from low to high with high inter-rater agreement $(\alpha=0.81)$, 50 inventory items of heterogeneous content were retained with the mean creativity indication ratings from 3.11 to 5.78 (possible range 0-6). The items had nonzero frequency of occurrence in the given sample of children. Table 1 lists in full the 50 behaviors used in the analyses.

\section{Results}

In order to provide answers to the research questions regarding the domain, gender and age differences in the creative behavior of children, the research used exploratory (EFA) and confirmatory factor analyses (CFA), as well as the multivariate analysis of variance. CFA were used to test whether the items, according to the expectations, were related to the hypothesized latent variables, indicating the structural (or factorial) construct validity. The content-based model was applied according to the EFA. The three domains were used as outlines for model specification, with all of the items retained in the same EFA based domains.

\section{Structure of creative behavior in children}

Out of the 50 inventory items, 12 components were initially extracted based on the Eigenvalues over 1 with the characteristic roots as follows: $11.44,3.32,2.35,1.78,1.64,1.42,1.29,1.19$, $1.16,1.10,1.04$, and 1.00. Principal Component Analysis (PCA) was performed considering the average communality at 0.57 , the Correlation Matrix Determinant at $1.35 \times 10^{-8}$, the Kaiser-Meyer-Olkin Measure of Sampling Adequacy at 0.92, and Bartlett's Test of Sphericity $\chi^{2}(1225)=14725.13, p=0.001$. Based on the scree plot, reproducibility and interpretability, the three-component PCA solution with oblique rotation was retained. 
DRUŠ. ISTRAŽ. ZAGREB GOD. 24 (2015), BR. 4 STR. $467-485$

RAČKI, Ž.: DOMAIN...
(1) TABLE 1 Factor loadings for Exploratory Factor Analysis with Oblimin Rotation of creative behaviors
These three components accounted for $34.22 \%$ of the common variance and are listed in Table 1. The first component was named Everyday creativity (E), the second, Scientific creativity (S), and the third, Artistic creativity (A). These names were chosen based on the contents that corresponded to the existing research on the creativity domains. Comprised of 21, 15 , and 14 items, respectively, E, A and S had acceptable reliabilities at $0.90,0.84$, and 0.77 , as listed in Table 3 . The second order PCA on the EAS domains resulted in one component explaining $66.73 \%$ of the common variance, with saturations of the domains in the same order at $0.89,0.83$, and 0.72 . Creative behavior as measured by the inventory can thus be perceived as hierarchical, with general creativity on top, the three broad domains and the activity types (literary, musical, etc.) in the middle, and the individual tasks within the activity types at the bottom.

CFAs were performed on square root transformed individual items for the single solution (Creativity - C), the two-component solution (Arts and Sciences - AS), and the three-component solution (Arts, Sciences, and Everyday creativity - EAS). With no modification indices used, the goodness-of-fit statistics and the RMSEA at 0.072 (CI 90\% 0.070-0.074) together pointed to the plausibility of the three-factor solution (EAS) in the gathered data. Multigroup CFAs were performed for gender and age, with the acceptable fit suggestive of comparable factor loadings and the correlations among the latent variables. For the boys and the girls, the CMIN/DF for the measurement weights and the structural covariance were 2.61 and 2.68, and the RMSEAs were $0.044(0.043-0.045)$ and $0.045(0.044-0.046)$. In the case of the third, the fifth, and the seventh grade, CMIN/DF for the measurement weights and the structural covariance were 2.53 and 2.53, and the RMSEAs were 0.043 (0.042-0.044) and 0.043 (0.042-0.044). The EFA and CFA results are listed in Table 1 and Table 2.

\begin{tabular}{lrrrr}
\hline Inventory items & $\mathrm{E}$ & $\mathrm{S}$ & $\mathrm{A}$ & $h$ \\
\hline 1 I make clay or plasticine figurines & $\underline{\underline{0.78}}$ & -0.09 & -0.05 & 0.56 \\
2 I make greeting cards and postcards & $\underline{\underline{0.74}}$ & -0.22 & 0.11 & 0.59 \\
3 I make collage pictures and objects & $\underline{\underline{0.73}}$ & -0.13 & -0.02 & 0.50 \\
4 I create masks & $\underline{\underline{0.61}}$ & -0.06 & 0.11 & 0.42 \\
5 & & & & \\
I draw or paint using standard equipment & $\underline{\underline{0.61}}$ & -0.07 & -0.02 & 0.35 \\
(acrylics, watercolor, charcoal, pencil, etc.) & $\underline{\underline{0.59}}$ & 0.18 & -0.15 & 0.38 \\
7 I make wire or wood figurines & $\underline{\underline{0.58}}$ & 0.18 & 0.05 & 0.44 \\
8 I draw on the computer using drawing software & $\underline{\underline{0.56}}$ & 0.06 & -0.11 & 0.30 \\
9 I make toys out of various materials & $\underline{\underline{0.55}}$ & 0.16 & -0.11 & 0.49
\end{tabular}

(Continued) 


\begin{tabular}{|c|c|c|c|c|c|}
\hline & (Continued) Inventory items & E & S & A & $\mathrm{h}$ \\
\hline 10 & I make jewelry out of thread, wool, fimo, plasticine or clay & $\underline{0.52}$ & -0.23 & 0.34 & 0.35 \\
\hline 11 & I construct paper figurines - origami & $\overline{0.50}$ & 0.14 & 0.10 & 0.38 \\
\hline 12 & I write compositions & $\overline{0.49}$ & -0.10 & 0.25 & 0.25 \\
\hline 13 & I provide others with play ideas & $\overline{0.47}$ & 0.13 & -0.06 & 0.36 \\
\hline 14 & I make posters & $\overline{0.47}$ & 0.01 & 0.23 & 0.36 \\
\hline 15 & I retell stories in my own way & $\overline{0.44}$ & 0.11 & 0.15 & 0.30 \\
\hline 16 & I write stories & $\overline{0.43}$ & -0.08 & 0.41 & 0.47 \\
\hline 17 & I make statues and sculptures out of different materials & $\overline{0.40}$ & 0.12 & 0.14 & 0.25 \\
\hline 18 & I create comics & $\overline{0.39}$ & 0.22 & 0.08 & 0.28 \\
\hline 19 & I invent magic tricks & $\overline{0.37}$ & 0.26 & 0.14 & 0.31 \\
\hline 20 & I invent new words & $\underline{0.37}$ & 0.26 & 0.09 & 0.28 \\
\hline 21 & I compose demanding and unusual tasks & $\overline{0.34}$ & 0.28 & 0.23 & 0.37 \\
\hline 22 & I come up with ideas for my own inventions & $\overline{0.22}$ & $\underline{0.55}$ & 0.04 & 0.42 \\
\hline 23 & I make my own video games & 0.00 & $\underline{0.53}$ & -0.09 & 0.27 \\
\hline 24 & I write my own computer programs (Pascal, Logo) & 0.01 & $\overline{0.50}$ & 0.04 & 0.26 \\
\hline 25 & I disassemble broken things and repair them & 0.36 & $\overline{0.49}$ & -0.11 & 0.41 \\
\hline \multirow[t]{2}{*}{26} & I create photomontage - photographs made & & & & \\
\hline & of different photographs & 0.02 & $\underline{0.47}$ & 0.21 & 0.30 \\
\hline 27 & I make animated movies on the computer & 0.13 & $\overline{0.45}$ & 0.03 & 0.25 \\
\hline 28 & I make robots - I do robotics & 0.02 & $\overline{0.44}$ & -0.14 & 0.20 \\
\hline 29 & I direct - artistically and technically manipulate films & -0.09 & $\overline{0.43}$ & 0.24 & 0.25 \\
\hline 30 & I'm making my own movie & -0.18 & $\overline{0.42}$ & 0.38 & 0.32 \\
\hline \multirow[t]{2}{*}{31} & I make miniature models of buildings and machines & & & & \\
\hline & (e.g. bridges or houses) out of different materials & 0.27 & $\underline{0.37}$ & -0.03 & 0.24 \\
\hline 32 & I make remote control toys & 0.09 & $\overline{0.36}$ & -0.09 & 0.15 \\
\hline 33 & I think up and conduct my own research & 0.23 & $\underline{0.36}$ & 0.28 & 0.38 \\
\hline 34 & I conduct my own extracurricular experiments and tests & 0.26 & $\overline{0.35}$ & 0.14 & 0.30 \\
\hline 35 & I make internet (web) pages & -0.07 & $\overline{0.34}$ & 0.15 & 0.14 \\
\hline 36 & I create whole new dances - choreographies & 0.25 & $-\overline{0.27}$ & $\underline{0.63}$ & 0.56 \\
\hline 37 & I invent new dance moves & 0.27 & -0.32 & $\overline{0.62}$ & 0.58 \\
\hline 38 & I make sketches for models of dresses - fashion designs & 0.32 & -0.27 & $\underline{0.53}$ & 0.50 \\
\hline 39 & I make up acting skits - short drama routines & 0.11 & 0.21 & $\underline{0.52}$ & 0.41 \\
\hline 40 & I write poetry & 0.36 & -0.12 & $\underline{0.52}$ & 0.52 \\
\hline 41 & I write plays - theatrical pieces with simple text & 0.25 & -0.01 & $\overline{0.47}$ & 0.37 \\
\hline \multirow[t]{2}{*}{42} & I create scenography (sets) - props and decorations for & & & & \\
\hline & the stage area of a theatre show & 0.14 & 0.03 & $\underline{0.46}$ & 0.29 \\
\hline 43 & I write novels & 0.08 & 0.22 & $\underline{0.46}$ & 0.33 \\
\hline 44 & I'm making my own music video & -0.10 & 0.28 & $\overline{0.46}$ & 0.30 \\
\hline \multirow[t]{2}{*}{45} & I write screenplays - detailed descriptions of plot & & & & \\
\hline & in my own film & 0.04 & 0.17 & $\underline{0.46}$ & 0.28 \\
\hline 46 & I compose vocal music - music made for singing & -0.00 & 0.17 & $\overline{0.45}$ & 0.26 \\
\hline 47 & I perform in a drama group & -0.07 & -0.11 & $\overline{0.44}$ & 0.18 \\
\hline 48 & I design shoes & 0.33 & -0.16 & $\overline{0.43}$ & 0.38 \\
\hline 49 & I play in a puppet troupe & -0.07 & 0.03 & $\underline{0.37}$ & 0.13 \\
\hline \multirow[t]{4}{*}{50} & I compose instrumental music - music performed & & & & \\
\hline & only on instruments & 0.05 & 0.16 & $\underline{0.31}$ & 0.16 \\
\hline & Eigenvalues & 11.44 & 3.32 & 2.35 & - \\
\hline & $\%$ of explained Variance & 22.88 & 6.64 & 4.69 & - \\
\hline
\end{tabular}

Note. Factor loadings $\geq 0.30$ are underlined. 


\begin{tabular}{|c|c|c|c|c|c|c|c|c|c|c|c|}
\hline Models & $\chi^{2}$ & $d f$ & $p$ & $\mathrm{CN}$ & NNFI & GFI & CFI & PNFI & SRMR & RMSEA & $\begin{array}{l}\text { RMSEA } \\
\text { CI } 90 \%\end{array}$ \\
\hline \multicolumn{12}{|c|}{ Independence } \\
\hline model & 51551.22 & 1225 & & & & & & & & & \\
\hline C & 6352.92 & 1175 & 0.000 & 169.63 & 0.89 & 0.68 & 0.90 & 0.84 & 0.075 & 0.094 & $0.092-0.095$ \\
\hline AS & 5603.12 & 1174 & 0.000 & 192.04 & 0.91 & 0.74 & 0.91 & 0.85 & 0.072 & 0.079 & $0.077-0.081$ \\
\hline EAS & 5088.89 & 1172 & 0.000 & 211.00 & 0.92 & 0.77 & 0.92 & 0.86 & 0.071 & 0.072 & $0.070-0.074$ \\
\hline \multicolumn{12}{|c|}{ Gender (EAS) } \\
\hline Girls & 3022.04 & 1172 & 0.000 & 173.55 & 0.92 & 0.76 & 0.92 & 0.84 & 0.066 & 0.066 & $0.063-0.069$ \\
\hline Boys & 2978.57 & 1172 & 0.000 & 184.28 & 0.89 & 0.77 & 0.89 & 0.80 & 0.070 & 0.064 & $0.061-0.067$ \\
\hline \multicolumn{12}{|l|}{ Age (EAS) } \\
\hline 3. grade & 2679.42 & 1172 & 0.000 & 134.11 & 0.91 & 0.71 & 0.91 & 0.82 & 0.077 & 0.073 & $0.069-0.076$ \\
\hline 5. grade & 2893.12 & 1172 & 0.000 & 121.61 & 0.91 & 0.67 & 0.92 & 0.83 & 0.086 & 0.082 & $0.078-0.085$ \\
\hline 7. grade & 2938.68 & 1172 & 0.000 & 123.68 & 0.87 & 0.68 & 0.87 & 0.77 & 0.093 & 0.081 & $0.078-0.084$ \\
\hline
\end{tabular}

(1) TABLE 2

Confirmatory factor analyses (CFA) for the one-, two-, and three-factor solution of the children's creative behavior as measured by the inventory

TABLE 3

Descriptive statistics for the three creativity domains as measured by the inventory
Note. $n=831 . \chi^{2}=$ Minimum Fit Function Chi-Square; $\mathrm{CN}=$ Hoelter Critical N; NNFI = Non-Normed Fit Index; GFI = Goodness of Fit Index; $\mathrm{CFI}=$ Comparative Fit Index; PNFI = Parsimony Normed Fit Index; SRMR = Standardized Root Mean Square Residual; RMSEA = Root Mean Square Error of Approximation; RMSEA CI 90\% = 90 Percent Confidence Interval for RMSEA.

\begin{tabular}{lrrrrrr}
\hline $\begin{array}{l}\text { Creativity } \\
\text { domains }\end{array}$ & $\begin{array}{r}n \text { of } \\
\text { items }\end{array}$ & $M$ & $S D$ & $\alpha$ & $\begin{array}{r}\text { Observed } \\
\text { range }\end{array}$ & Skew \\
\hline 1. Everyday (E) & 21 & 1.02 & 0.71 & 0.90 & $0-3.76$ & 0.95 \\
2. Artistic (A) & 15 & 0.44 & 0.56 & 0.84 & $0-3.20$ & 1.75 \\
3. Scientific (S) & 14 & 0.41 & 0.46 & 0.77 & $0-2.86$ & 1.81 \\
\hline
\end{tabular}

Note. All presented values are untransformed. $n=831$.

Potential range (0-4).

As expected, fair to poor factor loadings of individual items on their latent variables - as well as item cross-loadings, low communalities and the low percentage of the overall variance - proved to be problematic within the model fit presented in this study. The fit indices were lower than desired, and this model needs to be retailored before it can be used further. Due to the unbalanced number of items, as well as modification indices pointing to their error covariance for improvement of fit, low to high reliabilities (0.43-0.89) of discernable but heterogeneous creativity subscales within the broad EAS domains - for example, play (E), research (S), robotics (S), dance (A), music (A), or literary creativity (A) - need to be explored, elaborated and then confirmed in more detail, with at least three indicators in each subscale. Furthermore, the development of the underlying creativity theory as the explanation for the observed creative behavior correlations is needed. 
DRUŠ. ISTRAŽ. ZAGREB GOD. 24 (2015), BR. 4, STR. $467-485$

RAČKI, Ž.: DOMAIN...

$\rightarrow$ FIGURE

Percentages of children from the entire sample as self -assessed at the level of $\geq+1$ SD above the Everyday, the Artistic, and the Scientific creativity sample means, and their combinations (dashed circles are used to represent behavior prototypicality, not categorical boundaries)

\section{Discriminant validity of creativity domains}

With improved skewness and kurtosis of the EFA based item linear combinations through square root transformation, E, A and $\mathrm{S}$ were used to calculate the mean gender and age differences in the creative behaviors. E correlated significantly and positively with A and S, at $r(831)=0.65, p<0.001$, and $r(831)=0.49, p<0.001$. A and S were significantly and positively correlated as well, but somewhat lower, at $r(831)=0.35$, $p<0.001$. The domains of $\mathrm{E}$ and A correlated in the third, the fifth and the seventh grade at $r(278)=0.69, p<0.001, r(272)$ $=0.68, p<0.001, r(281)=0.60, p<0.001$; the domains $\mathrm{E}$ and $\mathrm{S}$ at $r(278)=0.58, p<0.001, r(272)=0.55, p<0.001, r(281)=0.48$, $p<0.001$; and the domains A and $\mathrm{S}$ at $r(278)=0.41, p<0.001$, $r(272)=0.41, p<0.001, r(281)=0.25, p<0.00$. The mean inter-item correlations for $\mathrm{E}$ in the third, the fifth, and the seventh grade were $0.29,0.32$ and 0.27 ; for A they were $0.25,0.30$ and 0.21 ; and for $S$ they were $0.17,0.20$ and 0.22 . For EAS as entire domains, the inter-correlation decreased with age, with means at $0.56,0.55$ and 0.44 in the third, the fifth, and the seventh grade. It could be hypothesized at this point that everyday, simple forms of creative behavior represent behavioral antecedents of more complex forms of creativity expected to occur later on. Concurrent with this reasoning are the longitudinal analyses of the predictive validity of simple creative thinking tasks in the context of adult creative accomplishments, as well as connections between play, playfulness and creativity (e.g., Russ, 2003; Torrance, 1966, 1995). To find out how domains overlapped in the sample, a Venn diagram of percentages was created, as displayed in Figure 1.

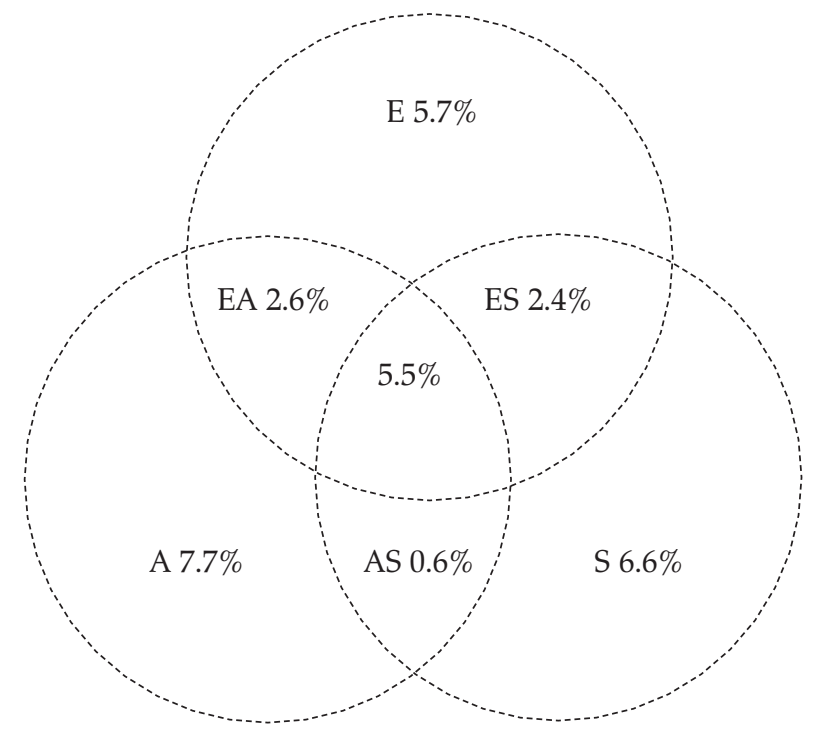


DRUŠ. ISTRAŽ. ZAGREB GOD. 24 (2015), BR. 4 STR. $467-485$

RAČKI, Ž.: DOMAIN...
Two-thirds of the children (572;68.8\%) rated themselves as rarely participating in extracurricular creative behaviors on their own $(<+1 \mathrm{SD} ; 58.4 \%$ girls and $78.8 \%$ boys). Under six percent $(5.5 \%)$ rated themselves as participating in creative behaviors in all the domains (EAS) at level $\geq+1 S D$. Less than one percent of children $(0.6 \%)$ rated themselves as creative at level $\geq+1 S D$, exclusively in AS. A closer overlap between EA and ES, rather than AS in the entire sample, regardless of age, is evident. More so, AS correlations declined, with 0.41 and 0.25 from the third to the seventh grade, which suggests the possibility of developmental changes in the partial domain specificity of the self-assessed creative behaviors, as well as the emergence of the $\mathrm{A}$ and $\mathrm{S}$ as the identifiable domains of creativity in children with age and gender. The remaining positive correlation between the AS domains is in line with the polymathy discussed by Root-Bernstein and Root-Bernstein (2004) among adult artistic scientists and scientific artists.

Listed according to the descending counts for the entire sample of 406 girls in Figure 1 are the presented areas of A, EAS, E, EA, ES, S, and AS numbered 60, 42, 36, 21, 4, 3, and 3. For the entire sample of 425 boys, in the same order, the counts were $4,4,11,1,16,52$, and 2 . The counts printed in bold point to the domain and gender differences in the creative behaviors, for example, with as many boys in the Sciences as there are girls in the Arts, $\chi^{2}(1, n=112)=0.57, p=0.450$. These gender differences, in line with research on gender differences and creativity (Baer \& Kaufman, 2011; He \& Wong, 2011), were further explored in detail by means of the multivariate analysis of variance.

\section{Domain, gender and age differences} in the creative behavior of children

A between-subjects multivariate analysis of variance (MANOVA) was performed for the boys and the girls in the third, the fifth and the seventh grade for the three creativity domains (EAS), as presented in Figure 2. Using Wilks' criterion, the domains were significantly affected by both gender, $\Lambda=0.51, F(3,823)$ $=264.12, p<0.001, \eta p^{2}=0.49$, and grade, $\Lambda=0.84, F(6,1646)$ $=25.43, p<0.001, \eta p^{2}=0.08$, as well as their significant interaction, $\Lambda=0.98, F(6,1646)=3.21, p=0.004, \eta p^{2}=0.01$. The $\eta p^{2}$ indicates that the multivariate variance of EAS is more strongly associated with gender than with age, or the interaction thereof. The analyses of variances (ANOVAs) on the EAS were conducted as follow-up tests.

The boys and the girls differed significantly in all the creativity domains $-\mathrm{A}, \mathrm{E}$ and $\mathrm{S}-$ in the following order: $F(1,830)=$ 483.78, $p<0.001, \eta p^{2}=0.37 ; F(1,830)=141.55, p<0.001, \eta p^{2}=$ $0.15 ; F(1,830)=6.02, p=0.014, \eta p^{2}=0.007$. Overall, the girls 
DRUŠ. ISTRAŽ. ZAGREB GOD. 24 (2015), BR. 4, STR. 467-485

RAČKI, Ž.: DOMAIN...

(1) FIGURE 2

Mean values for boys and girls on creativity domains in all grades (error bars represent standard mean error $(95 \% \mathrm{Cl})$ rated themselves as participating more frequently in the activities from the A and E domain, and the boys in those from the $S$ creativity domain. Significant grade differences were present for $E$ and $S$ at $F(2,830)=24.85, p<0.001, \eta p^{2}=0.06$ and $F(2,830)=7.89, p<0.001, \eta_{p}{ }^{2}=0.02$. Based on the Bonferroni adjustment for multiple comparisons, the mean of $\mathrm{E}$ was significantly higher in the third grade than in the seventh grade $(p<0.001)$. The opposite was true for the $\mathrm{S}$ domain; in other words, the mean of $S$ was significantly higher in the seventh grade in comparison to the mean in the third grade. There were no significant differences in A with respect to the grade. The significant interactions of gender and grade were found for the $\mathrm{A}$ and $\mathrm{S}$ domains, $F(2,830)=4.28, p=0.014, \eta_{\mathrm{p}}{ }^{2}=$ 0.01 , and $F(2,830)=4.39, p=0.013, \eta p^{2}=0.01$. The girls had higher overall A ratings in all the grades, peaking in the fifth grade, while the boys displayed a small decrease in the average $\mathrm{A}$ mean. The boys showed an increase in the $\mathrm{S}$ means, especially after the fifth grade, and the girls did not.

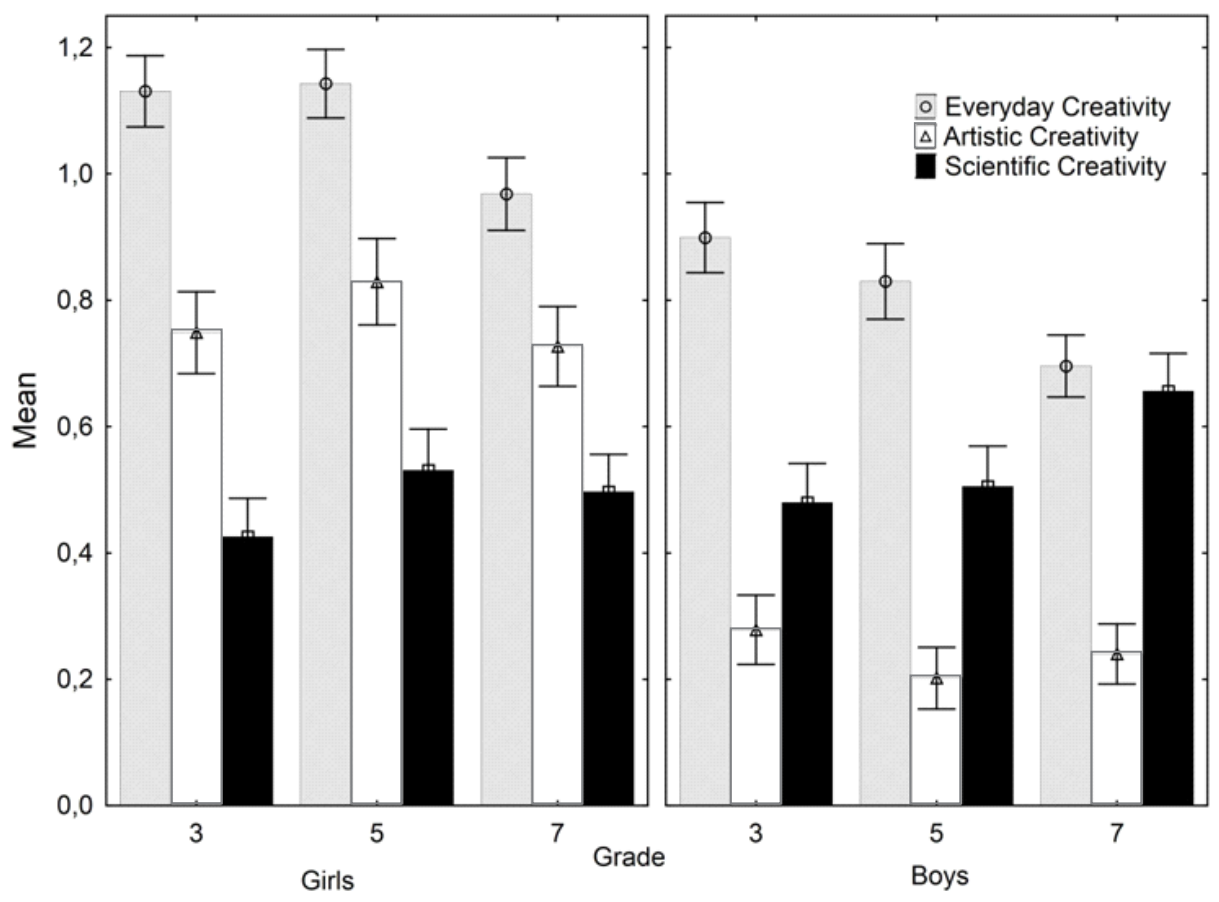

Discussion

The three broad creativity domains were defined as constituting the likely structure of creativity, similar to the creativity domains in adults (artists and scientists). There are con- 
DRUŠ. ISTRAŽ. ZAGREB GOD. 24 (2015), BR. 4 STR. $467-485$

RAČKI, Ž.: DOMAIN... struct similarities between the EAS creativity domains and the specific abilities (e.g., Lubinski, 2004; Wai et al., 2005). E corresponds to the display of spatial ability with its connection to behaviors related to manipulating $2 \mathrm{D}$ and $3 \mathrm{D}$ representations (drawing, painting, and modeling). S corresponds to the domain of quantitative-numeric ability related to the investigative, sequential and technically demanding creative behaviors. A corresponds to the domain of verbal-linguistic ability with its behavioral indicators of verbal content manipulation (writing), as well as sample observed gender asymmetries in line with the gender-related differences in intellectual abilities and vocational preferences. The complex forms of creative behavior in the EAS domains are indistinguishable from commonly perceived giftedness (e.g., a child creating remote control toys, or writing a novel), and this is in line with the close relationship between intelligence and creativity, as well as intelligence, creativity and task commitment in giftedness models (e.g., Renzulli, 1986). Giftedness as a developing expertise (Sternberg, 2001), as a part of the developmental interactions within and outside an individual (Feldman, 1986), can serve as a bridge between the observed domain, gender and age differences in the context of education.

\section{STUDY 2}

\section{Method}

\section{Participants}

The study participants were 54 female university students of teacher studies in their third, fourth or fifth and final year of study, with the age range from 22 to 26 . They were chosen as a convenience sample, but also in order to represent the education generalists, that is, prospective teachers who will teach all of the school subjects in grades 1-4 to children aged 6-12. As part of their university studies, the participants had experience observing and educating children of the particular age group included in this research.

\section{Materials and procedure}

The students were divided into four groups of comparable sizes at random, and they were treated as raters of subjectively perceived characteristics of individual creative behaviors. A larger group of behaviors was used, including those 50 listed in Table 1 that are the focus of this study. Other rated behaviors included more than three hundred items such as $I$ watch TV, or I play football. The behaviors were written on $10 \times$ $5 \mathrm{~cm}$ cards and shuffled. With high inter-rater agreement as measured by the Cronbach alpha and the Intraclass Correla- 
DRUŠ. ISTRAŽ. ZAGREB GOD. 24 (2015), BR. 4, STR. $467-485$

RAČKI, Ž.: DOMAIN... tion Coefficient, the first group of raters independently rated each of the behaviors regarding their own subjective interpretation of age-appropriateness of all behaviors from 1-7, with 1 meaning for younger children, and 7 for older children. The second, the third and the fourth participant group rated from 1-7 how much task-commitment was required for the usual performance (low to high), how much declarative and procedural knowledge each behavior required for the usual performance (low to high), and how gender appropriate (for boys or for girls) the behaviors were considered. The participants were unaware of the research aim.

\section{Results and discussion}

Doing research, creating web-pages, or writing novels, as opposed to drawing and painting, collage making, or making greeting cards, were rated as more appropriate for older children than younger children. Creating one's own videogames, writing computer programs, or making animated movies were rated as requiring more task commitment, while giving play ideas to others or telling stories in one's own way were rated

(1) TABLE 4

Summary of Psychometric Properties of consensually assessed Item Characteristics, Item Means and their Intercorrelations as a Function of Gender and Age as requiring comparatively less task commitment. Doing extracurricular experiments or composing music, as opposed to drawing and painting, were rated as requiring more knowledge. Fashion design, jewelry making, acting or choreography, in contrast to creating remotely operated toys, robots out of robotics sets, or making miniature models of buildings and machines, were rated as more appropriate for girls than boys.

\begin{tabular}{lrrrrrrr}
\hline & $\begin{array}{r}\text { N of } \\
\text { raters }\end{array}$ & $\alpha$ & ICCa & 1. & 2. & 3. & 4. \\
\hline 1. Age appropriateness & 13 & 0.94 & 0.47 & & & & \\
2. Task commitment & 16 & 0.94 & 0.38 & $0.88^{* *}$ & & & \\
3. Knowledge required & 13 & 0.92 & 0.32 & $0.86^{* *}$ & $0.82^{* *}$ & & \\
4. Gender appropriateness & 12 & 0.96 & 0.67 & $-0.54^{* *}$ & $-0.60^{* *}$ & $-0.73^{* *}$ & - \\
5. Inventory grade item means & & & & & & & \\
Boys $\quad$ Third (mean for $n=140$ ) & & & $-0.56^{* *}$ & $-0.62^{* *}$ & $-0.34^{*}$ & 0.05 \\
$\quad$ Fifth (for $n=137$ ) & & & $-0.48^{* *}$ & $-0.53^{* *}$ & -0.25 & -0.05 \\
$\quad$ Seventh (for $n=148$ ) & & & -0.17 & $-0.31^{*}$ & 0.03 & $-0.32^{*}$ \\
$\quad$ Girls $\quad$ Third (mean for $n=138$ ) & & & $-0.71^{* *}$ & $-0.74^{* *}$ & $-0.63^{* *}$ & $0.52^{* *}$ \\
$\quad$ Fifth (for $n=135$ ) & & & & $-0.61^{* *}$ & $-0.70^{* *}$ & $-0.60^{* *}$ & $0.54^{* *}$ \\
$\quad$ Seventh (for $n=133$ ) & & & $-0.51^{* *}$ & $-0.65^{* *}$ & $-0.52^{* *}$ & $0.47^{* *}$ \\
Full sample mean for $n=831$ & & & $-0.60^{* *}$ & $-0.70^{* *}$ & $-0.48^{* *}$ & $0.29^{*}$ \\
\hline
\end{tabular}

Note. nitems $=50$. aIntraclass correlation coefficient, absolute agreement of raters, single measure. Gender appropriateness: $1-7$, meaning for boys to for girls. ${ }^{*} \mathrm{p}<0.05 ;{ }^{* *} \mathrm{p}<0.01$.

The highest agreement among the raters was connected to what was gender appropriate. The negative correlations 
DRUŠ. ISTRAŽ. ZAGREB GOD. 24 (2015), BR. 4 STR. $467-485$

RAČKI, Ž.: DOMAIN... listed in Table 4 indicate that the creative behaviors rated as more appropriate for girls were the ones that required lower level of knowledge, lower task commitment, and were more appropriate for younger children, namely those belonging to the $\mathrm{E}$ and A creativity domains. The currently biased provision of extracurricular activities in elementary schools for creativity development in the A domain (Rački et al., 2015) may serve girls' interests better. On the other hand, it may also send them a message of the ways in which girls should be creative (E and A). Under the influence of the Art Bias, teachers might fail to recognize or encourage creativity in boys because they are overall less frequently involved in the A domain, and more involved in the S creativity domain. This finding has educational implications with respect to gender-appreciative and democratic curriculum planning regarding $\mathrm{E}, \mathrm{A}$ and $\mathrm{S}$ creative program features for both younger and older boys and girls.

\section{GENERAL DISCUSSION}

The frequency with which children displayed creative behaviors was closely tied to task commitment, but it was also tied to the required knowledge for the usual performance of each individual creative behavior. This may imply that if children do not commit themselves to creative behaviors - some of which may require acquisition of rich declarative and procedural knowledge to achieve standard performance - the decrement in everyday creativity may represent nothing more than age-appropriate behavior.

Overall, research shows that the simpler creativity means decrease, the domain of scientific creativity emerges and diverges from the artistic creativity and the everyday creativity domain with age, with gender-related differences favoring girls in the $\mathrm{E}$ and the $\mathrm{A}$, and boys in the $\mathrm{S}$ creativity domain. Nevertheless, one must point out that the domains were not homogenous or monolithic at all. The creative behaviors strongly related to knowledge acquisition (for example, robotics), guidance or appreciation by adults (for example, acting in a drama group or composing instrumental music) loaded poorly on one general creativity factor, which renders the model of general creativity more inaccurate as children grow up. In this way, once the intra-domain behavioral contents are more clearly explored and mapped, the EAS model fit is in need of further exploration, improvement or dismissal in line with the initial guidelines provided in this study. The moderate but declining correlations between creativity domains with respect to age may not be all about discriminant validity issues. The developmental shifts towards the increase in the 
DRUŠ. ISTRAŽ. ZAGREB GOD. 24 (2015), BR. 4, STR. $467-485$

RAČKI, Ž.: DOMAIN... complexity of performance caused by knowledge acquisition may result in the occurring specificity of creative behavior with age as one of the probable explanations.

The items in the EAS domains may share intra-domain similarities and cross-domain correlations for reasons that go beyond the superficial method-effects of self-ratings present in this study. Everyday creativity had the highest mean in all the gender and age groups, and it may be the age-appropriate expression or manifestation of a general cluster of traits (e.g., playfulness and commitment) predictive of adult creative accomplishments. It can serve as a bridge towards more complex learning- and skill acquisition-related creative behaviors because it is normative in its most basic form of inquisitive, exploratory behavior perceived as play with easily accessible materials (paper, glue, collage, modelling clay and colors). In his research and insights about creativity, Torrance (1995) stated that creativity development requires time. This statement, produced by a lifelong scholar and teacher on creativity, seems absolutely relevant for this study and needs to be reiterated. Structuring activities for nurturing various domain-specific creativities in children, which translates into providing specific, hands-on opportunities at least during obligatory elementary education, may remedy the inequalities in creative behavior observed in this study. This is especially true in light of the concerns regarding the Art Bias in teachers' implicit theories on creativity.

Creative behavior is nested within a specific context. A child's motivation to participate in certain creative behaviors may hardly ever compensate for a lack of resources needed in and for creativity, such as a musical instrument, access to specialized knowledge, or prolonged tutoring. Existing research (Dumais, 2006) outlined the socioeconomically imposed constraints on creative behavior in children that may severely impair the creativity model fit. Because of this, the multilevel CFA modelling of creative behavior structure throughout one's development in different socioeconomic groups will need to be performed in order to account for the socioeconomic factors shaping the creativity development and performance.

Although males and females produce original, meaningful, and relevant ideas (on divergent thinking tasks) equally well as they age (Bart, Hokanson, Sahin, \& Abdulsamea, 2015), the partial domain specificity observed in this study needs to be taken into account when planning educational opportunities for children. General creativity, which is an elusive concept within the everyday educational practice, is under an unintended threat of skewness towards the $\mathrm{E}$, A or S domain, depending on the chosen creativity program. More educationally viable are the informed provisions of domain specif- 
DRUŠ. ISTRAŽ. ZAGREB GOD. 24 (2015), BR. 4 STR. $467-485$

RAČKI, Ž.: DOMAIN...

\section{CONCLUSIONS}

\section{LIMITATIONS AND IMPLICATIONS FOR FURTHER RESEARCH}

There are limitations inherent in this study that caution to over-generalize the results, the most important being the relatively small number of items used in the specific spatiotemporal and economical educational circumstances to which the sample of children in this study was exposed. Because only a single method of data collection was used, it is difficult to determine whether the observed correlations are the result of the true relationships or the results of the shared method. There are also concerns regarding creativity construct validity and breadth, as well as the structural properties of the proposed creativity domains, yet this is subject to further research through the provision of all the items available in this study.

ic activities and the inclusion of progressively more complex contents as children acquire knowledge and skills within that activity. In this manner, when taken as a behavior (how to do least at the behavioral level. By using the behavioral indicators of creativity and their assessment by the creators of educan be established in future research between creativity and development.

In addition to dealing with the creativity structure issues, the present study established a connection between the tions to which all children are systematically exposed. More research such as this is needed in creativity model building sues inherent in the structure of creativity and how it changes over time.

This research provided the initial support to the: 1) three-domadomain averages with respect to age, as well as the decrement in the inter-domain average correlations implying the ges in the domain averages with age, with overall hicher quency of $\mathrm{E}$ and $\mathrm{A}$ for girls, and S for boys, 4) negative itemmean correlations with the consensually assessed item leve knowledge for its usual performance, and 5) age-related changes in line with the gender related observed asymmetries of creative behavior among the general population.

This initial pool of behaviors is in need of elaboration. Gender 
DRUŠ. ISTRAŽ. ZAGREB GOD. 24 (2015), BR. 4, STR. $467-485$

RAČKI, Ž.: DOMAIN... and age were the only variables measured. Intelligence, socioeconomic status, available educational opportunities, parental engagement, peer influences and teacher, school, or broader historical and geographical influences were not taken into account, and this should be added to the future research.

Nevertheless, this research has implications for educational practice, as it specifies the construct of creativity to observable, hands-on behavior readily accessible to teachers during instruction. The research provides opportunities to turn the individual creative behavior items into single lessons, projects or educational programs aimed at the EAS creativity development.

\title{
ACKNOWLEDGEMENTS
}

\begin{abstract}
A I wish to thank the children, their parents, teachers, and the students of teacher studies for devoting their time to participate in this study.
\end{abstract}

\section{REFERENCES}

Amabile, T. M. (1982). Social psychology of creativity: A consensual assessment technique. Journal of Personality and Social Psychology, 43(5), 997-1013. doi:/10.1037/0022-3514.43.5.997

Amabile, T. M. (1996). Creativity in context. Update to The social psychology of creativity. Boulder, CO: Westview Press Inc.

Baer, J. (2013). Teaching for creativity: Domains and divergent thinking, intrinsic motivation, and evaluation. In M. B. Gregerson, J. C. Kaufman, \& H. T. Snyder (Eds.), Teaching creatively and teaching creativity (pp. 175-181). New York: Springer. doi:/10.1007/978-1-46145185-3_13

Baer, J., \& Kaufman, J. (2005). Bridging generality and specificity: The Amusement Park Theoretical (APT) model of creativity. Roeper Review, 27(3), 158-163. doi:/10.1080/02783190509554310

Baer, J., \& Kaufman, J. C. (2011). Gender differences in creativity. The Journal of Creative Behavior, 42(2), 75-105. doi:/10.1002/j.2162-6057.2008. tb01289.x

Bart, W. M., Hokanson, B., Sahin, I., \& Abdulsamea, M. A. (2015). An investigation of the gender differences in creative thinking abilities among 8th and 11th grade students. Thinking Skills and Creativity, 17, 17-24. doi:/10.1016/j.tsc.2015.03.003

Buss, D. M., \& Craik, K. H. (1983). The act frequency approach to personality. Psychological Review, 90(2), 105-126. doi:/10.1037/0033-295 X.90.2.105

Carson, S., Peterson, J. B., \& Higgins, D. M. (2005). Reliability, validity, and factor structure of the Creative Achievement Questionnaire. Creativity Research Journal, 17(1), 37-50. doi:/10.1207/s15326934crj1701_4

Chan, S., \& Yuen, M. (2014). Creativity beliefs, creative personality and creativity-fostering practices of gifted education teachers and 
DRUŠ. ISTRAŽ. ZAGREB GOD. 24 (2015), BR. 4 STR. $467-485$

RAČKI, Ž.: DOMAIN... regular class teachers in Hong Kong. Thinking Skills and Creativity, 14, 109-118. doi:/10.1016/j.tsc.2014.10.003

Dumais, S. A. (2006). Elementary school students' extracurricular activities: The effects of participation on achievement and teachers' evaluations. Sociological Spectrum, 26(2), 117-147. doi:/10.1080/02732 170500444593

Feldman, D. H. (1986). Giftedness as a developmentalist sees it. In R. J. Sternberg, \& J. E. Davidson (Eds.), Conceptions of giftedness (pp. 285-305). New York: Cambridge University Press.

Glăveanu, V. P. (2014). Revisiting the "art bias" in lay conceptions of creativity. Creativity Research Journal, 26(1), 11-20. doi:/10.1080/104004 19.2014.873656

Han, K. (2003). Domain-specificity of creativity in young children: How quantitative and qualitative data support it. Journal of Creative Behavior, 37(2), 117-142. doi:/10.1002/j.2162-6057.2003.tb00829.x

Hattie, J. A. C. (2012). Visible learning for teachers. London: Routledge. He, W., \& Wong, W. (2011). Gender differences in creative thinking revisited: Findings from analysis of variability. Personality and Individual Differences, 51(7), 807-811. doi:/10.1016/j.paid.2011.06.027

Hong, E., \& Milgram, R. M. (2010). Creative thinking ability: Domain generality and specificity. Creativity Research Journal, 22(3), 272-287. doi:/10.1080/10400419.2010.503535

Ivcevic, Z. (2007). Artistic and everyday creativity: An act-frequency approach. Journal of Creative Behavior, 41(4), 271-290. doi:/10.1002/ j.2162-6057.2007.tb01074.x

Kaufman, J. C., \& Baer, J. (2004). Sure, I'm creative - but not in mathematics!: Self-reported creativity in diverse domains. Empirical Studies of the Arts, 22(2), 143-155. doi:/10.2190/26HQ-VHE8-GTLN-BJJM

Kaufman, J. C., Cole, J. C., \& Baer, J. (2009). The construct of creativity: Structural model for self-reported creativity ratings. Journal of Creative Behavior 43(2), 119-134. doi:/10.1002/j.2162-6057.2009.tb01310.x

Lubinski, D. (2004). Introduction to the special section on cognitive abilities: 100 years after Spearman's (1904) "General intelligence', objectively determined and measured". Journal of Personality and Social Psychology, 86(1), 96-111. doi:/10.1037/0022-3514.86.1.96

Milgram, R. M., \& Livne, N. L. (2005). Creativity as a general and a domain-specific ability: The domain of mathematics as an exemplar. In J. C. Kaufman, \& J. Baer (Eds.), Creativity across domains: Faces of the muse. London: Lawrence Erlbaum Associates Publishers.

Rački, Ž., Katalenić, A., \& Gregorović, Ž. (2015). Self-reported creativity of primary school teachers and students of teacher studies in diverse domains, and implications of creativity relationships to teaching mathematics in the primary school. In Z. Kolar-Begović, R. Kolar-Šuper, \& I. Đurđević Babić (Eds.), Higher goals in mathematics education (pp. 283-302). Osijek: Josip Juraj Strossmayer University of Osijek, Faculty of Education and Department of Mathematics.

Renzulli, J. S. (1986). The three-ring conception of giftedness: A developmental model of creative productivity. In R. J. Sternberg, \& 
DRUŠ. ISTRAŽ. ZAGREB GOD. 24 (2015), BR. 4, STR. $467-485$

RAČKI, Ž.: DOMAIN...
J. E. Davidson (Eds.), Conceptions of giftedness (pp. 53-92). New York: Cambridge University Press.

Root-Bernstein, R. S., \& Root-Bernstein, M. (2004). Artistic scientists and scientific artists: The link between polymathy and creativity. In R. J. Sternberg, E. L. Grigorenko, \& J. L. Singer (Eds.), Creativity: From potential to realization (pp. 127-151). Washington, DC: American Psychological Association. doi:/10.1037/10692-008

Runco, M. A., \& Johnson, D. J. (2002). Parents' and teachers' implicit theories of children's creativity: A cross-cultural perspective. Creativity Research Journal, 14(3-4), 427-438. doi:/10.1207/S15326934CR J1434_12

Runco, M. A., \& Jaeger, G. J. (2012). The standard definition of creativity. Creativity Research Journal, 24(1), 92-96. doi:/10.1080/104004 19.2012.650092

Russ, S. W. (2003). Play and creativity: Developmental issues. Scandinavian Journal of Educational Research, 47(3), 291-303. doi:/10.1080/ 00313830308594

Silvia, P. J., Kaufman, J. C., \& Pretz, J. E. (2009). Is creativity domain-specific? Latent class models of creative accomplishments and creative self-descriptions. Psychology of Aesthetics, Creativity, and the Arts, 3(3), 139-148. doi:/10.1037/a0014940

Sternberg, R. J. (2001). Giftedness as developing expertise: A theory of the interface between high abilities and achieved excellence. High Ability Studies, 12(2), 159-179. doi:/10.1080/13598130120084311

Torrance, E. P. (1966). Torrance Tests of Creative Thinking. Bensenville: Scholastic Testing Service, INC.

Torrance, E. P. (1995). Insights about creativity: Questioned, rejected, ridiculed, ignored. Educational Psychology Review, 7(3), 313-322. doi:/10. 1007/BF02213376

Wai, J., Lubinski, D., \& Benbow, C. P. (2005). Creativity and occupational accomplishments among intellectually precocious youth: An age 13 to age 33 longitudinal study. Journal of Educational Psychology, 97(3), 484-492. doi:/10.1037/0022-0663.97.3.484

\section{Područne, rodne i dobne razlike u kreativnom ponašanju djece}

Željko RAČKI

Fakultet za odgojne i obrazovne znanosti, Osijek

Cili je ovoga istraživanja bio ispitati odnose područija, roda i dobi u kreativnom ponašanju djece. Istraživanjem su postavliena pitanja o modelu kreativnosti zbog značajnih implikacija kreativnosti na obrazovanje i razvoj nastavnih programa, kao i na poboljšanje kreativne nastave i nastave za kreativnost $u$ djece na razini osnovne škole. Sudionici su bili djeca od 8 do 15 godina i studenti učiteljskoga studija. Rezultati su pokazali potencijalnu strukturu područja 
DRUŠ. ISTRAŽ. ZAGREB GOD. 24 (2015), BR. 4 STR. 467-485

RAČKI, Ž.: DOMAIN... kreativnoga ponašanja diece, rodom određene promiene $u$ prosjecima područja s dobi i bliske odnose predanosti i stjecanja znanja s kreativnosti. Nalazi ovog istraživanja interpretirani su prema konstruktu kreativnosti i njegovu mierenju te u kontekstu obrazovanja.

Ključne riječi: kreativnost, kreativno-produktivna darovitost, djeca, obrazovni ciljevi, pristranost prema umjetnosti 